\title{
Effect of insulin-like growth factor I (IGF-I) at high concentrations on blastocyst development of bovine embryos produced in vitro
}

\author{
G. A. Palma ${ }^{1}$, M. Müller ${ }^{2}$ and G. Brem ${ }^{1,2}$ \\ ${ }^{1}$ Bavarian Research Center in Reproductive Biology, BFZF, 85764 Badersfeld, Germany; and ${ }^{2}$ Institute of \\ Animal Breeding and Genetics, Veterinary University of Vienna, 1210 Vienna, Austria
}

\begin{abstract}
This study was carried out to determine the effects of oestrous cow serum containing insulin-like growth factor I (IGF-I) and supplementation with recombinant IGF-I on subsequent development of bovine embryos produced in vitro. When culture medium was supplemented with oestrous cow serum containing $34.8 \mathrm{ng}$ endogenous IGF-I $\mathrm{ml}^{-1}$, more embryos $(P<0.01)$ developed to blastocysts by day 9 and more blastocysts hatched on day 13 after insemination $(P<0.01)$ than in the control group. The effect of the addition of 10 , 50 and $100 \mathrm{ng}$ IGF-I $\mathrm{ml}^{-1}$ to culture media containing oestrous cow serum and granulosa cells was also evaluated. Supplementation with $10 \mathrm{ng}$ IGF-I $\mathrm{ml}^{-1}$ did not improve embryo development at any stage. The addition of 50 and $100 \mathrm{ng}$ IGF-I ml ${ }^{-1}$ did not affect development during the first three cell divisions. However, on day 7 these groups yielded a higher embryo rate than did the control group. Similarly, the proportion of blastocysts on day 9 was enhanced. The addition of $100 \mathrm{ng}$ IGF-I $\mathrm{ml}^{-1}$ also increased the proportion of blastocysts. These data suggest that IGF-I at high concentrations accelerates the development to the blastocyst stage by shortening the transition from the morula to the blastocyst stage. The addition of $100 \mathrm{ng}$ IGF-I ml ${ }^{-1}$ increased the proportion of hatched blastocysts on day 13. The addition of oestrous cow serum and IGF-I to TCM 199 free of granulosa cells did not increase the proportion of embryos on day 7. However, the progress to blastocysts and hatched blasstocysts on days 9 and 13 was significantly lower $(P<0.05)$. The addition of IGF-I to culture medium without oestrous cow serum but with granulosa cells resulted in significantly lower embryo development than in the control group or in the group supplemented with oestrous cow serum and IGF-I $(P<0.01)$. The results support the hypothesis that culture media containing high concentrations of IGF-I combined with oestrous cow serum and granulosa cells can improve the development of embryos produced in vitro.
\end{abstract}

\section{Introduction}

Successful methods have been developed for producing bovine embryos in vitro. Seven days after the fertilization of oocytes selected for production in vitro, up to $40 \%$ have developed into embryos (Brackett and Zuelke, 1993). However, the percentage of blastocysts (day 9) and hatched blastocysts (day 13) is lower than expected (Krefft, 1993; Palma et al., 1993) because the development of some embryos is arrested at earlier stages. Thus, it is necessary to improve the culture media to enhance morula and blastocyst development.

Growth factors have been shown to play a regulatory role in the functioning of the ovary (Adashi $e t$ al., 1985; Carson $e t$ al., 1989; Oliver et al., 1989; Echternkamp et al., 1994) and the uterus (Bringstock et al., 1989; Boehm et al., 1990; Chegini et al., 1992; Persson et al., 1992) resulting in a trophic effect on the endometrium and the embryo. Insulin-like growth factor I (IGF-I) is an important growth factor in blood and is of

Revised manuscript received 3 March 1997. particular importance in the interaction between the uterine endometrium and conceptus (Simmen et al., 1993).

Several research groups reported that addition of growth factors to culture media stimulates the development of bovine embryos in vitro (Rinderknecht and Humbel, 1988; Coskun et al., 1991; Larson et al., 1992; Harper and Kaye, 1992; Keefer, 1992). Earlier studies showed that IGF-I induces mitosis of granulosa cells (Armstrong and Xia, 1993), the maturation of oocytes (Harper and Brackett, 1993; Lorenzo et al., 1994) and bovine embryo development (Kaye et al., 1992). Insulin-like growth factors (IGFs) have a high affinity for soluble binding proteins that can modulate receptor binding, and hence influence the biological activity of IGFs.

The purpose of this study was to examine the effect of supplementing the culture medium with different concentrations of IGF-I on the development of in vitro matured and fertilized (IVM/IVF) oocytes when oestrous cow serum was used. In addition, the development of embryos up to the stage of hatched blastocysts was compared with the development of embryos produced in protein-free medium, to assess whether 
serum and IGF-I supplementation can stimulate preimplantation development of bovine embryos in in vitro culture. The effect of supplementation with IGF-I in TCM 199 free of serum and granulosa cells was also investigated to determine whether IGF-I acts synergistically with oestrous cow serum and directly on embryos or via granulosa cells. The development of embryos produced in different culture systems was evaluated by their ability to develop in vitro into blastocysts at day 9 and into hatched blastocysts at day 13 after fertilization.

\section{Material and Methods}

\section{Collection of oocytes, maturation, fertilization and culture}

Bovine ovaries were obtained from a local abattoir and were transported to the laboratory in phosphate-buffered saline (PBS, pH 7.35, $284 \mathrm{mOsmol} \mathrm{l}^{-1}$ ) at $25-30^{\circ} \mathrm{C}$. Within $4 \mathrm{~h}$ oocytes were aspirated from follicles $2-8 \mathrm{~mm}$ in diameter using a micro/macro aspirator (Labotect, Göttingen) and a $20 \mathrm{~g}$ needle. Only cumulus-oocyte complexes with multilayered, compact cumulus cells and dark, evenly granulated cytoplasm were allocated to the experimental groups.

For in vitro maturation the oocytes were cultured in TCM 199 (Seromed, Berlin), supplemented with L-glutamine (100 mg $\left.\mathrm{l}^{-1}\right), \mathrm{NaHCO}_{3}\left(3 \mathrm{~g} \mathrm{l}^{-1}\right)$, Hepes (1400 mg l-1), pyruvate (250 $\left.\mathrm{mg} \mathrm{l}^{-1}\right)$, L-lactic-calcium-salt $\left(600 \mathrm{mg} \mathrm{l}^{-1}\right)$, gentamycin (55 $\mathrm{mg} \mathrm{1}^{-1}$ ), porcine FSH (pFSH, $10 \mu \mathrm{g} \mathrm{ml}^{-1}$, Schering, Kenitworth, NJ) and $10 \%(\mathrm{v} / \mathrm{v})$ heat-treated $\left(56^{\circ} \mathrm{C}, 30 \mathrm{~min}\right)$ oestrous cow serum. Concentrations of hormones and IGF-I were determined using a radioimmunoassay as described by Schams et al. (1991). Briefly, IGF-I was determined by radioimmunoassay after acid-ethanol extraction of $50 \mu \mathrm{l}$ serum. Separation of bound and free hormones was accomplished by a combination of second-antibody technique with $12 \%$ polyethylene glycol. Intra- and interassay coefficients of variation were $<10 \%$ and $<16 \%$, respectively. The oestrous cow serum contained $34.8 \mathrm{ng}^{\mathrm{IGF}-\mathrm{I} \mathrm{ml}}{ }^{-1}, 5.7 \mathrm{pg}$ oestradiol $\mathrm{ml}^{-\mathrm{I}}, 0.7 \mathrm{ng}$ progesterone $\mathrm{ml}^{-1}, 50.6 \mathrm{ng} \mathrm{FSH} \mathrm{ml}^{-1}$ and $4.9 \mathrm{ng} \mathrm{LH} \mathrm{ml}^{-1}$. Thirty selected cumulus-oocyte complexes were each placed in a $400 \mu \mathrm{l}$ drop and cultured for $20 \mathrm{~h}$ at $39^{\circ} \mathrm{C}$, in a humidified atmosphere of $5 \% \mathrm{CO}_{2}: 95 \%$ air. Frozen semen from the same bull was used for all in vitro fertilizations. Each straw was thawed in a water-bath at $39^{\circ} \mathrm{C}$ for $10 \mathrm{~s}$. Motile spermatozoa were separated by a modified swim-up technique in a Tyrode's lactate solution supplemented with BSA $\left(6 \mathrm{mg} \mathrm{ml}^{-1}\right.$, Sigma, St Louis, MO), sodium pyruvate $\left(0.1 \mu \mathrm{g} \mathrm{ml}{ }^{-1}\right.$, Sigma) and gentamicin $\left(50 \mu \mathrm{l} \mathrm{ml}^{-1}\right.$, Seromed). Semen was washed once in the same medium $(3-5 \mathrm{ml})$ by centrifugation at $200 \mathrm{~g}$ for $10 \mathrm{~min}$. The supernatant was discarded, and the sperm pellet was resuspended in $100-200 \mu \mathrm{l}$ of the same medium. Sperm concentration was determined and resuspended spermatozoa were added to a final concentration of $1.0 \times 10^{6}$ spermatozoa $\mathrm{ml}^{-1}$.

After maturation the cumulus-oocyte complexes were transferred to $400 \mu \mathrm{l}$ drops of fert-Talp medium (Bavister and Yanagimachi, 1977) supplemented with $6 \mathrm{mg} \mathrm{BSA} \mathrm{ml}^{-1}$ (Sigma) and $10 \mu \mathrm{g}$ heparin $\mathrm{ml}^{-1}$ (Sigma).

In vitro fertilization was performed for $20-24 \mathrm{~h}$ at $39^{\circ} \mathrm{C}$ in a humidified atmosphere of $5 \% \mathrm{CO}_{2}: 95 \%$ air. After fertilization the cumulus cells were removed from the oocytes by vortexing for $1 \mathrm{~min}$ in a $10 \mathrm{ml}$ conical tube containing $400 \mu \mathrm{l}$ culture medium. Subsequently 30 denuded oocytes were placed in each $400 \mu \mathrm{l}$ drop of TCM 199 with $0.8-1.2 \times 10^{6}$ granulosa cells $\mathrm{ml}^{-1}$, covered with equilibrated paraffin oil and cultured for 3-13 days in a humidified atmosphere of $5 \% \mathrm{CO}_{2}, 5 \% \mathrm{O}_{2}$ and $90 \% \mathrm{~N}_{2}$ at $39^{\circ} \mathrm{C}$. The culture was examined on days $2,3,7,9$ and 13 after insemination to determine the cleavage rate (day 2), development rate of embryos (day 7) and blastocysts (days 9 and 13). In all experiments the effect of culture conditions on early embryo development was evaluated by counting the number of blastomeres on day 3 . The embryos produced were freed from the zona pellucida by a brief exposure to PBS at $\mathrm{pH} 2.5$ for $40-60 \mathrm{~s}$. The blastomeres were dissociated by exposing them to $0.25 \%(\mathrm{w} / \mathrm{v})$ trypsin in PBS for 10 to $20 \mathrm{~min}$ and counted. Embryo development was evaluated by determining the proportion of morulae and blastocysts on day 7 , blastulation on day 9 and the formation of hatched blastocysts on day 13.

\section{Experiment 1}

The presumptive zygotes $(n=1417)$ were cultured in $400 \mu \mathrm{l}$ drops of either TCM 199 plus 10\% oestrous cow serum containing $348 \mathrm{ng}$ endogenous IGF-I ml ${ }^{-1}\left(34.8 \mathrm{ng} \mathrm{ml}^{-1}\right.$ in culture droplets) $(n=690)$ or in TCM 199 without oestrous cow serum (control, $n=719$ ) for 3-13 days. For the evaluation of the developmental capacity of embryos, 588 presumptive zygotes were cultured for 13 days with 10\% oestrous cow serum and 617 without oestrous cow serum with seven replications. For measuring the effect of oestrous cow serum on the number of blastomeres on day 3 after insemination, 110 oocytes were cultured with $10 \%$ oestrous cow serum to evaluate 86 embryos and 102 oocytes were cultured without oestrous cow serum as a control group to evaluate 82 embryos on day 3 after insemination.

\section{Experiment 2}

In this experiment 1308 oocytes were selected for IVM/IVF. After fertilization, the 680 presumptive zygotes were cultured in TCM 199 plus 10\% oestrous cow serum containing, as in Expt 1, 34.8 $\mathrm{ng}$ endogenous IGF-I $\mathrm{ml}^{-1}$ supplemented with 10 ng human recombinant IGF-I $\mathrm{ml}^{-1}$ (Boehringer Mannheim, Mannheim) $(n=680$ ), or without the IGF-I supplement (control, $n=628$ ). Thus the total concentration of IGF-I was $44.8 \mathrm{ng} \mathrm{ml}^{-1}$ and $34.8 \mathrm{ng} \mathrm{ml}^{-1}$, respectively. The number of blastomeres on day 3 was assessed by examining 155 oocytes from the group cultured in media supplemented with IGF-I and 223 oocytes from the control group. The remaining oocytes (525 from the supplemented group and 405 from the control group) were cultured for 13 days, and the rate of development was assessed. The treatments were replicated seven times.

\section{Experiment 3}

Recombinant IGF-I was added at concentrations of 50 and $100 \mathrm{ng} \mathrm{ml}^{-1}$ to TCM 199 containing $10 \%$ oestrous cow serum (34.8 $\mathrm{ng}$ endogenous IGF-I ml ${ }^{-1}$ in culture droplets), giving 
Table 1. Effect of $10 \%$ oestrous cow serum on embryo development rate

\begin{tabular}{|c|c|c|c|c|c|}
\hline $\begin{array}{l}\text { Serum } \\
(\%)\end{array}$ & $\begin{array}{l}\text { Oocytes } \\
(n)\end{array}$ & $\begin{array}{l}\text { Cleavage } \\
(\text { day } 2 \text { ) }\end{array}$ & $\begin{array}{c}\text { Morulae and } \\
\text { blastocysts } \\
\text { (day 7) }\end{array}$ & $\begin{array}{l}\text { Blastocysts } \\
\text { (day 9) }\end{array}$ & $\begin{array}{c}\text { Hatched } \\
\text { blastocysts } \\
\text { (day 13) }\end{array}$ \\
\hline 0 & 588 & $\begin{array}{l}81.6 \% \\
(480)\end{array}$ & $\begin{array}{c}34.2 \% \\
(201)\end{array}$ & $\begin{array}{c}17 \% \\
(100)^{*}\end{array}$ & $\begin{array}{l}7.1 \% \\
(42)^{*}\end{array}$ \\
\hline 10 & 617 & $\begin{array}{l}80.4 \% \\
(496)\end{array}$ & $\begin{array}{c}38.4 \% \\
(237)\end{array}$ & $\begin{array}{l}29.0 \% \\
(179)^{*}\end{array}$ & $\begin{array}{l}21.5 \% \\
(133)^{*}\end{array}$ \\
\hline
\end{tabular}

Values in parentheses are numbers of oocytes reaching that stage.

*Values within columns differ $(P<0.01)$.

concentrations of 84.8 and $134.8 \mathrm{ng}^{\text {IGF-I ml }}{ }^{-1}$, respectively. As in Expt 1, these two groups (50 $\mathrm{ng} \mathrm{ml}^{-1}, n=550$ and $100 \mathrm{ng} \mathrm{ml}^{-1}, n=638$ ) were compared with embryos developed in TCM 199 plus $10 \%$ oestrous cow serum but without recombinant IGF-I ( $n=608$ oocytes). For determination of early developmental capacity, groups of oocytes (control, $n=180 ; 50 \mathrm{ng} \mathrm{ml}^{-1}, n=156$; and $100 \mathrm{ng} \mathrm{ml}^{-1}, n=183$ ) were used to produce the embryos (142, 111 and 143, respectively) to determine the number of blastomeres on day 3. The remaining oocytes (control, $n=428 ; 50 \mathrm{ng} \mathrm{ml}^{-1}, n=394$ and $100 \mathrm{ng} \mathrm{ml}^{-1}, n=455$ ) were used to evaluate the development of embryos up to day 13 . The treatments were replicated seven times.

\section{Experiment 4}

After fertilization of the selected oocytes (1533) the presumptive zygotes were divided at random into four groups according to the supplementation of TCM199: 10\% oestrous cow serum plus $100 \mathrm{ng}$ IGF-I ml ${ }^{-1}$ without granulosa cells (GC) (IGF-I + oestrous cow serum, $n=411$ ), 100 ng IGF-I $\mathrm{ml}^{-1}$ plus $50 \times 10^{3}$ granulosa cells but without oestrous cow serum (IGF-I + GC, $n=388$ ), IGF-I without oestrous cow serum or GC (IGF-I, $n=397$ ) and 10\% oestrous cow serum plus GC but without IGF-I (control, $n=337$ ). The treatments were replicated five times.

\section{Statistical analyses}

The percentage of embryos developing into cleaved embryos (day 2), morulae and blastocysts (day 7), blastocysts (day 9) and hatched blastocysts (day 13) was expressed as the proportion of all oocytes cultured for maturation. Differences were tested for statistical significance by Chi-square test with Yates' correction. When the frequency of developed embryos was expected to be below 5, Fischer's Exact Probability Test was used in addition. The cell number on day 3 was subjected to analysis of variance. $P<0.05$ was considered to be significant.

\section{Results}

\section{Experiment 1: effect of oestrous cow serum}

The mean percentages of embryos developing to different stages when cultured in TCM 199 supplemented with 10\% oestrous cow serum is shown in Table 1. There was no significant difference in the rate of embryo development on days 2 and 7. However, oestrous cow serum had a significant effect on the number of blastocysts and hatched blastocysts produced by day 9 and day 13 , respectively $(P<0.01$; Table 1$)$. There were no significant differences in the proportions of $2-4$, 5-8 and >8-cell embryos produced when the media were supplemented with $10 \%$ oestrous cow serum $(16.3 \%, 49.5 \%$ and $34.1 \%$, respectively, compared with $18.3 \%, 47.6 \%$ and $34.1 \%$, respectively, for the control group).

\section{Experiment 2: effect of medium supplemented with $10 \mathrm{ng}$ recombinant IGF-I $\mathrm{ml}^{-1}$}

There was a significant difference in cleavage rate between the group treated with additional $10 \mathrm{ng}$ IGF-I $\mathrm{ml}^{-1}$ and the control group $(P<0.05$; Table 2$)$. However, there was no significant difference between the groups on day 7 (morula and blastocyst formation) day 9 (blastocyst formation) or day 13 (hatching of blastocysts). The number of blastomeres on day 3 was not different between the group supplemented with IGF-I $(19.3 \%, 46.3 \%$ and $34.4 \%)$ and the control group $(17.3 \%, 48.2 \%$ and $34.5 \%$ for $2-4,5-8$ and $>8$-cell embryos, respectively, $P>0.05$ ).

Experiment 3: effect of supplementation with 50 and $100 \mathrm{ng}$ recombinant IGF-I $\mathrm{ml}^{-1}$

There was no significant difference in the cleavage rate on day 2 (Table 3 ) or in the proportion of blastomeres $(2-4,5-8$ and $>8$-cell embryos) on day 3 between the groups supplemented with 0,50 or $100 \mathrm{ng}$ IGF-I ml ${ }^{-1}(19.1 \%, 47.5 \%$ and $33.4 \%$ compared with $19.8 \%, 45.9 \%$ and $34.3 \%$, and $16.9 \%$, $47.5 \%$ and $35.6 \%$, respectively, $P>0.05$ ).

On day 7 and day 9 the rate of morula and blastocyst formation was higher when 50 or 100 ng IGF-I was added to the culture medium than when embryos were cultured in the control medium without IGF-I (Table 3). Similarly when the presumptive zygotes were cultured in medium containing $100 \mathrm{ng}$ IGF-I $\mathrm{ml}^{-1}$, the number of hatched blastocysts on day 13 was significantly higher $(P>0.01)$ than in the control group.

The percentage of oocytes reaching different stages of embryo development by days 7 and 9 are shown (Figs 1 and 2). On day 7 the proportion of oocytes reaching the morula and blastocyst stages was not different between embryos cultured 
Table 2. Effect of additional insulin-like growth factor I ( $10 \mathrm{ng}$ IGF-I $\mathrm{ml}^{-1}$ ) on bovine embryo development rate

\begin{tabular}{|c|c|c|c|c|c|}
\hline $\begin{array}{l}\text { IGF-I } \\
\text { added } \\
\left(\mathrm{ng} \mathrm{ml}^{-1}\right)\end{array}$ & $\begin{array}{c}\text { Oocytes } \\
(n)\end{array}$ & $\begin{array}{c}\text { Cleavage } \\
\text { (day 2) }\end{array}$ & $\begin{array}{c}\text { Morulae and } \\
\text { blastocysts } \\
\text { (day 7) }\end{array}$ & $\begin{array}{c}\text { Blastocysts } \\
\text { (day 9) }\end{array}$ & $\begin{array}{c}\text { Hatched } \\
\text { blastocysts } \\
\text { (day 13) }\end{array}$ \\
\hline 0 & 405 & $\begin{array}{l}77.0 \% \\
(312)^{*}\end{array}$ & $\begin{array}{c}37.7 \% \\
(153)\end{array}$ & $\begin{array}{c}28.9 \% \\
(117)\end{array}$ & $\begin{array}{c}21.0 \% \\
(85)\end{array}$ \\
\hline 10 & 525 & $\begin{array}{l}81.7 \% \\
(429)^{*}\end{array}$ & $\begin{array}{c}37.1 \% \\
(195)\end{array}$ & $\begin{array}{c}28.4 \% \\
(149)\end{array}$ & $\begin{array}{c}20.8 \% \\
(109)\end{array}$ \\
\hline
\end{tabular}

Values in parentheses are the number of oocytes that reach that stage.

*Values within columns are significantly different $(P<0.05)$.

Table 3. The effect of additional insulin-like growth factor I (50 and $100 \mathrm{ng}$ IGF-I ml ${ }^{-1}$ ) on the development rate of embryos

\begin{tabular}{cccccc}
\hline $\begin{array}{l}\text { IGF-I } \\
\left(\mathrm{ng} \mathrm{ml}^{-1}\right)\end{array}$ & $\begin{array}{c}\text { Oocytes } \\
(\mathrm{n})\end{array}$ & $\begin{array}{c}\text { Cleavage } \\
\text { (day 2) }\end{array}$ & $\begin{array}{c}\text { Morulae and } \\
\text { blastocysts } \\
(\text { day } 7)\end{array}$ & $\begin{array}{c}\text { Blastocysts } \\
(\text { day 9) }\end{array}$ & $\begin{array}{c}\text { Hatched } \\
\text { blastocysts } \\
\text { (day 13) }\end{array}$ \\
\hline 0 & 428 & $80.1 \%$ & $32.0 \%$ & $28.0 \%$ & $21.2 \%$ \\
50 & 394 & $(343)$ & $(137)^{\mathrm{c}}$ & $(120)^{\mathrm{a}, \mathrm{c}}$ & $(91)^{\mathrm{c}}$ \\
100 & $80.7 \%$ & $36.5 \%$ & $34.5 \%$ & $25.1 \%$ \\
& $(318)$ & $(144)$ & $(136)^{\mathrm{b}}$ & $38.2 \%$ & $32.1 \%$ \\
\end{tabular}

Values in parentheses are the number of oocytes that reach that stage.

Values within columns with different superscripts differ significantly ${ }^{a, b} p<0.05,{ }^{c, d} p<0.01$.

with $50 \mathrm{ng}$ IGF-I $\mathrm{ml}^{-1}$ and those cultured without IGF-I $(62.6 \%)$. The addition of $100 \mathrm{ng}$ IGF-I ml ${ }^{-1}$ resulted in a higher proportion of blastocysts $(68.0 \%, P<0.01)$ compared with the control group and there were significantly more early $(P<0.01)$ and expanded blastocysts $(P<0.05)$ in this group.

The early blastocyst arrest seen on day 9 decreased when $100 \mathrm{ng}$ IGF-I ml ${ }^{-1}(6.4 \% ; P<0.05)$ was added to the culture media compared with the control group (13.1\%). Supplementation with $50 \mathrm{ng}$ IGF-I $\mathrm{ml}^{-1}$ had no significant effect (11.8\%). Supplementation with $100 \mathrm{ng}$ IGF-I $\mathrm{ml}^{-1}$ resulted in a lower proportion of blastocysts $(6.4 \%)$ compared with the control group $(13.1 \%)$ and with the group supplemented with $50 \mathrm{ng}$ IGF-I $\mathrm{ml}^{-1}(12.5 \%)$; however, this difference was not significant $(P<0.06)$. In the group cultured in medium with $100 \mathrm{ng}$ IGF-I $\mathrm{ml}^{-1}$ more blastocysts had hatched by day $9(67.2 \%)$ than in the control group $(54.7 \% ; P<0.05)$, indicating a more rapid development of blastocysts (Fig. 2).

The proportion of blastocysts that progressed to hatched blastocysts from day 9 to day 13 was $75.8 \%(91 / 120), 72.8 \%$ (99/136) and $83.4 \%$ (146/175) for 0, 50 and $100 \mathrm{ng}$ IGF-I ml ${ }^{-1}$, respectively, and did not differ significantly between groups.

\section{Experiment 4: effect of supplementation with $100 \mathrm{ng}$ IGF-I ml ${ }^{-1}$} together with granulosa cells and oestrous cow serum

There was no difference in the cleavage rate on day 2 between the four treatments groups (Table 4). On day 7 the group cultured with IGF-I and oestrous cow serum but without granulosa cells did not differ from the control group. However, the groups cultured with IGF-I but without oestrous cow serum, and without granulosa cells or oestrous cow serum had significantly fewer morulae and blastocysts on day 7 and fewer blastocysts on days 9 and $13(P<0.01)$.

On days 9 and 13 the proportions of blastocysts and hatched blastocysts after culture in oestrous cow serum plus IGF-I and in IGF-I alone were significantly lower than in the control group $(P<0.05)$. There was no significant difference in the embryonic development rate between the groups cultured with IGF-I and granulosa cells and IGF-I alone.

\section{Discussion}

The results of the present study suggest that the in vitro development of bovine embryos improves in a culture medium containing high concentration of IGF-I in addition to oestrous cow serum and granulosa cells.

In the present study, the concentrations of IGF-I in serum are similar to those reported by Echternkamp et al. (1990) with exogenous IGF-I present at the usual concentration for cell culture (10 $\left.\mathrm{ng} \mathrm{ml}^{-1}\right)$ and at higher concentrations.

The addition of $10 \mathrm{ng}$ IGF-I ml ${ }^{-1}$ to TCM 199 containing $10 \%$ oestrous cow serum had a positive effect on the cleavage rate $(P<0.05)$. However, the difference in the cleavage rate 


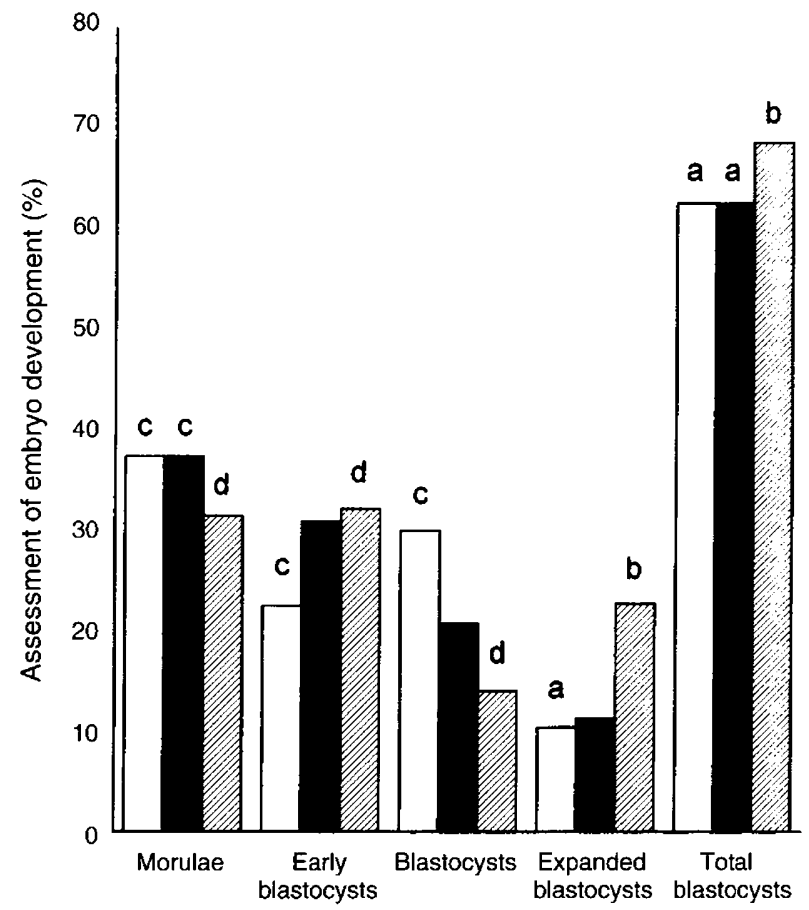

Fig. 1. Effect of insulin-like growth factor I (IGF-I) on the development of bovine embryos on day 7 after insemination. The percentage of morulae, early blastocysts, blastocysts, expanded blastocysts and total blastocysts present 7 days after culture of presumptive zygotes (day 1) in TCM 199 plus $10 \%$ oestrous cow serum, containing $38.4 \mathrm{ng}$ endogenous IGF-I ml ${ }^{-1}$ supplemented with $\mathrm{O}(\square), 50(\boldsymbol{M})$ and 100 $(\circlearrowright)$ ng exogenous human recombinant IGF-I $\mathrm{ml}^{-1}$. Total numbers of embryos examined at the IGF-I final concentrations of $34.8,84.8$ and $134.8 \mathrm{ng} \mathrm{IGF-1} \mathrm{ml}{ }^{-1}$ were $107,107,137$, respectively. Statistical analysis is a comparison by means of Chi-square analysis: ${ }^{a, b} P<0.05$ and ${ }^{\mathrm{c} d} \mathrm{P}<0.01$.

may have been only a temporary effect, as no positive effect on the number of blastomeres (on day 3) was detectable 1 day later. Similarly, the supplementation of culture media with 50 or $100 \mathrm{ng}$ IGF-I ml ${ }^{-1}$ did not affect early embryo development. These results corroborate other studies conducted on bovine embryos (Barnes and First, 1991), but conflict with reports on mice. Kaye et al. (1992) showed that the supplementation of IGF-I stimulates the in vitro development of two-cell mouse embryos $48 \mathrm{~h}$ after in vitro fertilization. These divergent observations may be due to developmental characteristics of murine and bovine embryos. Blastulation in mouse embryos, for instance, occurs within $72 \mathrm{~h}$ after IVF, whereas this occurs in cow embryos 5 to 7 days after IVF and thus growth factor receptors are expressed later than in murine embryos (Schultz et al., 1992).

The results presented here also corroborate studies conducted on bovine embryos which demonstrated that IGF-1 has no effect on IVM/IVF/IVC embryos during the transition period from maternal to embryonic control of development (Barnes and First, 1991). In accordance with this, the control medium containing neither IGF-I nor serum was not inferior in stimulating early development to media supplemented with oestrous cow serum and different concentrations of IGF-I.

Whereas $10 \mathrm{ng}$ IGF-I $\mathrm{ml}^{-1}$ did not improve bovine embryo development, the supplementation of 50 and $100 \mathrm{ng} \mathrm{ml}^{-1}$

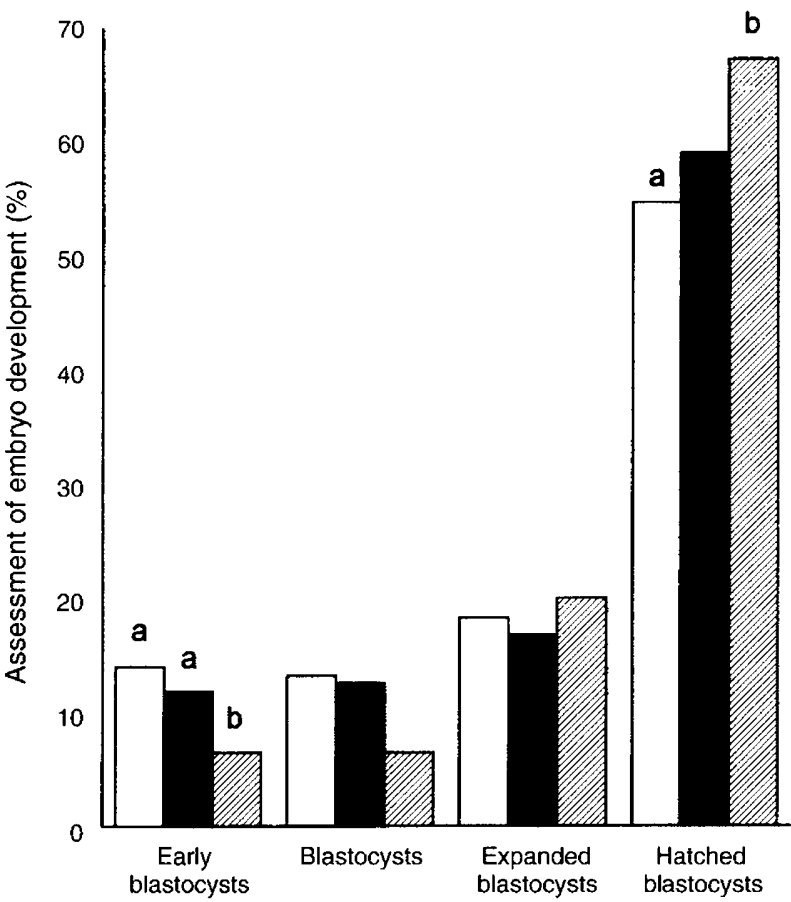

Fig. 2. Effect of insulin-like growth factor I (IGF-I) on the development of blastocysts on day 9 after insemination. Percentage of early blastocysts, blastocysts, expanded blastocysts and hatched blastocysts 8 days after culture of presumptives zygotes (day I) in TCM 199 plus $10 \%$ oestrous cow serum, containing $38.4 \mathrm{ng}$ endogenous IGF-I ml ${ }^{-1}$ supplemented with $O(\square), 50(\square)$ and $100(\nabla)$ ng human recombinant IGF-I $\mathrm{ml}^{-1}$. Total numbers of embryos examined at the IGF-I final concentrations of $34.8,84.8$ and 134.8 ng IGF-I were 137,144 and 186 , respectively. Statistical analysis is a comparison by means of Chi-square analysis: ${ }^{a . b} p<0.05$.

increased the yield of embryos on day 7. These data are consistent with the results from the studies in mice by Harvey and Kaye (1992) but conflict with results of studies reporting that no positive effect on bovine embryo development was observed on day 7 after fertilization when IGF-I was added at $50 \mathrm{ng} \mathrm{m}^{-1}$ (Herrler et al., 1993). These authors may have failed to demostrate clearly the positive effect of IGF-I because they used a lower contentration of $\mathrm{LH}$ in the maturation medium, which could have caused lower developmental rates (Herrler et al., 1993).

The results of the present study also suggest that there is a dose-response relationship between IGF-I and embryonic development, since the medium containing $50 \mathrm{ng}$ IGF-I $\mathrm{ml}^{-1}$ yielded a lower proportion of hatched blastocysts on day 9 than the medium containing $100 \mathrm{ng}$ IGF-I ml ${ }^{-1}$.

The result with $100 \mathrm{ng}_{\text {IGF-I ml }}{ }^{-1}$ is similar to that reported by Matsui $e$ al. (1994) but is inconsistent with the report of Lee and Fukui (1995), who used a culture medium without supplementation with oestrous cow serum or another protein source.

In Expt 3 embryonic development in TCM 199 plus granulosa cells was compared with that in TCM 199 plus granulosa cells supplemented with $10 \%$ oestrous cow serum containing $34.8 \mathrm{ng}$ endogenous IGF-I ml $\mathrm{ml}^{-1}$ and significant differences were found until day 7 .

In Expts 1 and 4, the proportion of hatched blastocysts on day 9 and of hatched blastocysts on day 13 was considerably 
Table 4. The effect of granulosa cells (GC), oestrous cow serum (ECS) and insulin-like growth factor I (100 $\mathrm{ng} \mathrm{IGF-I} \mathrm{ml}^{-1}$ ) on the development rate of bovine embryos

\begin{tabular}{|c|c|c|c|c|c|}
\hline Group & $\begin{array}{c}\text { Oocytes } \\
\langle n\rangle\end{array}$ & $\begin{array}{c}\text { Cleavage } \\
\text { (day 2) }\end{array}$ & $\begin{array}{c}\text { Morulae and } \\
\text { blastocysts } \\
\text { (day 7) }\end{array}$ & $\begin{array}{c}\text { Blastocysts } \\
\text { (day 9) }\end{array}$ & $\begin{array}{l}\text { Hatched } \\
\text { blastocysts } \\
\text { (day 13) }\end{array}$ \\
\hline $\mathrm{ECS}+\mathrm{GC}$ (control) & 337 & $79.5 \%(268)$ & $35.9 \%(121)^{\mathrm{c}}$ & $32.5 \%(108)^{\mathrm{a}, \mathrm{c}}$ & $30.3 \%(102)^{a, c}$ \\
\hline $\mathrm{ECS}+\mathrm{IGF}-\mathrm{I}$ & 411 & $79.6 \%(327)$ & $30.2 \%(124)^{c}$ & $25.5 \%(105)^{b, c}$ & $23.8 \%(98)^{b}$ \\
\hline GC + IGF-I & 388 & $79.6 \%(309)$ & $19.6 \% \quad(76)^{d}$ & $12.1 \%(47)^{d}$ & $7.2 \% \quad(28)^{d}$ \\
\hline IGF-I & 397 & $79.6 \%(316)$ & $16.1 \% \quad(64)^{d}$ & $8.6 \% \quad(34)^{d}$ & $5.0 \% \quad(20)^{d}$ \\
\hline
\end{tabular}

Values within columns with different superscripts differ significantly: ${ }^{a, b} P<0.05$; ${ }^{c . d} p<0.01$.

lower with the culture medium containing granulosa cells and $100 \mathrm{ng}$ IGF-I ml ${ }^{-1}$. TCM 199 with granulosa cells was able to stimulate development up to day 7 , but then the development of the embryos decreased. The granulosa cells in TCM 199 without oestrous cow serum did not build a monolayer as did the control group supplemented with serum. Whether the TCM 199 without serum directly affected the development of embryos or acted via the granulosa cells was not evaluated in this study. In addition, embryonic development was significantly lower when the culture medium was supplemented only with IGF-I. These results support the contention that there is an interaction between oestrous cow serum, IGF-I and granulosa cells in the in vitro development of IVM/IVF embryos (Thibodeaux et al., 1995). Furthermore the results reported here suggest that IGF-I acts on the development of bovine embryos indirectly, via granulosa cells and in agreement with previous studies that showed that supplementation with growth factors could be beneficial to embryonic development in the absence of serum but could not replace it (Palma et al., 1995).

This supposition is also corroborated by the finding that IGF-I receptors are located in the plasma membrane of granulosa cells (Adashi et al., 1988) and that IGF-I stimulates the proliferation and differentiation of these cells (Spicer et al., 1993). In addition, the IGF-I binding capacities of granulosa cells are enhanced by FSH and LH (Veldhuis and Rogers, 1987; Gong et al. 1993) and oestrogens.

The fact that a high culture density improves embryo development (Wiley et al., 1986; Paria and Dey, 1990; Palma et al. 1992; Ferry et al., 1994; Keefer et al. 1994) provides support for a cooperative interaction between preimplantation embryos due to the growth factors released by them. Interestingly, the addition of $100 \mathrm{ng}$ IGF-I ml ${ }^{-1}$ did not only result in a higher proportion of hatched blastocysts, but also accelerated the formation of early and expanded blastocysts on day 7 . It has been reported that mouse embryos develop faster in high culture densities (Paria and Dey, 1990; Lane and Gardner, 1991) and that the transition from morula to blastocyst stage occurs $24 \mathrm{~h}$ earlier in ovine and bovine embryos produced in vitro than in those collected after superovulation (Walker et al., 1992; Greve et al., 1993), which may be due to the higher temperature in the incubator (Greve et al., 1993).

The results presented here indicate that high concentrations of exogenous IGF-I added to the culture system in the presence of granulosa cells, serum and endogenous IGF-I accelerate embryo development. In the experiments reported here, the in vitro development of embryos cultured with $100 \mathrm{ng}$ IGF-I $\mathrm{ml}^{-1}$ was not reduced on day 13 of culture as well as after freezing (Willemsen et al., 1995). As embryonic development was only examined in vitro up to day 13 this provides only limited evidence and has to be substantiated by testing the in vivo viability after transfer. The mechanism by which IGF-I exerts a mitogenic and differentiating effect on in vitro cultured embryos is not known. In in vitro culture IGF-I can act directly on the embryo via receptors on morulae and blastocysts (Mattson et al., 1988; Heyner et al., 1989). In conclusion IGF-I plays an important role in the IVM/IVF/IVC development of bovine embryos and it improves the development of embryos produced in vitro when added to culture media containing oestrous cow serum and granulosa cells. Under these culture conditions, treatment with IGF-I at high concentrations does not have a negative effect but may enhance the development of IVM/IVF embryos cultured in vitro for a relatively long time, for example 13 days.

The authors would like to thank D. Schams for the analysis of hormones and IGF-I. This work was supported by a grant from Bayerische Forschungsstiftung.

\section{References}

Adashi EY, Resnick CE, D'ercole AJ, Svoboda ME, van Vyk JJ (1985) Insulin-like growth factors as interovarian regulators of granulosa cell growth and function. Endocrine Reviews 6 400-420

Adashi EY, Resnick CE, Hernandez ER, Svoboda ME and Van Wyk JJ (1988) Characterization and regulation of a specific cell membrane receptor for somatomedin C/insulin like growth factor I in culture rat granulosa cells Endocrinology 122 194-201

Armstrong DT and Xia P (1993) Differential mitogenic actions of insulin-like growth factor-I and FSH on bovine cumulus cells and granulosa cells Theriogenology 39181 (Abstract)

Barnes FL and First NL (1991) Embryonic transcription in in vitro cultured bovine embryos Molecular Reproduction and Development 29 117-123

Bavister BD and Yanagimachi R (1977) The effects of sperm extracts and energy sources on the motility and acrosome reaction of hamster spermatozoa in vitro. Biology of Reproduction 16 228-237

Boehm KD, Daimon M, Gorodeski IG, Sheean LA, Utian WH Ilan J (1990) Expression of the insulin-like and platelet-derived growth factor genes in human uterine tissues. Molecular Reproduction and Development 27 93-101

Brackett B and Zuelke KA (1993) Analysis of factors involved in the in vitro production of bovine embryos Theriogenology 39 43-64

Bringstock DR, Heap RB, Brown KD (1989) Polypetide growth factors in uterine tissues and secretions Journal of Reproduction and Fertility 85 747-758

Carson RS, Zhang Z, Hutchinson LA, Herington AC, Findlay JK (1989) Growth factors in ovarian function Journal of Reproduction and Fertility 85 735-746 
Chegini N, Rossi MJ, Masterson BJ (1992) Platelet-derived growth factor (PDGF), epidermal growth factor (EGF), and EGF and PDGF $\beta$-receptors in human endometrial tissue: localization and in vitro action Endocrinology 130 2373-2385

Coskun SA, Sanbuissho A, Lin YC, Rikihisa Y (1991) Fertilizability and subsequent developmental ability of bovine oocytes matured in medium containing epidermal growth factor (FGF) Theriogenology 36 485-494

Echternkamp SE, Spicer LJ, Gregory KE, Canning SF and Hammond JM (1990) Concentrations of insulin-like growth factor-I in blood and ovarian follicular fluid of cattle selected for twins Biology of Reproduction 43 8-14

Echternkamp SE, Howard HJ, Roberts AJ, Grizzle J, and Wise T (1994) Relationships among concentrations of steroids, Insulin-like Growth Factor-I, and Insulin-like factor binding proteins in ovarian follicular fluid of beef cattle Biology of Reproduction 51 971-981

Ferry L, Mermillod P, Massip A and Dessy F (1994) Bovine embryos cultured in serum-poor oviduct-conditioned medium need cooperation to reach the blastocyst stage Theriogenology $\mathbf{4 2} 445-453$

Gong JG, Mc Bride D, Bramley TA, Webb R (1993) Effects of recombinant bovine somatotrophin, insulin-like growth factor-I and insulin on the proliferation of bovine granulosa cells in vitro Journal of Endocrinology 139 $7-75$

Greve T, Avery B and Callesen H (1993) Viability of in vivo and in vitro produced bovine embryos Reproduction in Domestic Animals 28 164-169

Harper KM and Brackett G (1993) Bovine blastocysts development after in vitro maturation in a defined medium with epidermal growth factor and low concentrations of gonadotropins Biology of Reproduction 48 409-416

Harper KM, Kaye P (1992) Enhanced bovine oocyte quality after in vitro maturation (IVM) with insulin-like growth factor-I (IGF-I) and gonadotropins Biology of Reproduction and Development Supplement 167 (Abstract)

Harvey MB and Kaye PL (1992) Insulin-like growth factor-1 stimulates growth of mouse preimplantation embryos in vitro Molecular Reproduction and Development 31 195-199

Herrler A, Lucas-Hahn A, Niemann H (1993) Effects of insulin-like growth factor-I on in vitro production of bovine embryos Theriogenology 37 $1213-1214$

Heyner S, Rao IV, Jarret L and Smith RM (1989) Preimplantation mouse embryos internalise maternal insulin via receptor-mediated endocytosis: pattern of uptake and functional correlations Developmental Biology 137 45-58

Kaye PL, Bell KL, Beebe LF, Dunglison LFS, Gardner HG, Harvey MB (1992) Insulin-like growth factors (IGFs) in preimplantation development Reproduction Fertility and Development 4 373-386

Keefer CL (1992) Development of bovine embryos produced in vitro cultured individually in a simple medium: effect of EGF and TGF $\beta 1$ Theriogenology 37 236

Keefer CL, Stice SL, Paprocki AM and Golueke P (1994) In vitro culture of embryos. Cooperative interaction among embryos and role of growth factors Theriogenology 41 1322-1331

Krefft H (1993) Untersuchungen zur Wirkung von Wachstumsfaktoren bei der Entwicklung von Rinderembryonen in vitro PhD Thesis pp 1-135 LudwigMaximilian University Munich

Lane M and Gardner DK (1991) Effect of incubation volume and embryo density on the development and viability of mouse embryos in vitro Proceedings of the Symposium on Preimplantation Embryo Development Newton Massachusetts 33 (Abstract)

Larson RC, Ignotz GG, Currie WB (1992) Platelet derived growth factor (PDGF) stimulates development of bovine embryos during fourth cell cycle Development $155821-826$

Lee ES and Fukui Y (1995) Effect of various growth factors in a defined cultured medium on in vitro development of bovine embryos matured and fertilized in vitro Theriogenology 00? $71-83$

Lorenzo PL, Illera MJ, Illera JC and Illera M (1994) Enhancement of cumulus expansion and nuclear maturation during bovine oocyte maturation in vitro by the addition of epidermal growth factor and insulin-like growth factor I Journal of Reproduction and Fertility $101697-701$

Mattson BA, Rosenblum IY, Smith RM and Heyner S (1988) Autoradiographic evidence for insulin and insulin-like growth factor binding to early mouse embryos Diabetes 37 585-589

Matsui M, Takahashi Y, Hishinuma M, Kanagawa H (1994) Effect of insulin and insulin-like growth factor on the development of bovine embryos Journal of Mammalian Ova Research 11 132-133

Oliver JE, Aitman TJ, Powell JF, Wilson CA, Clayton RN (1989) Insulin-like growth factor-I gene expression in the rat ovary is confined to the granulosa cells of developing follicles Endocrinology 124 2671-2676

Palma GA and Brem G (1995) Effect of growth factors IGF-I, TDGF- $\alpha$, EGF and PDGF on development of in vitro produced bovine blastocysts Theriogenology 43291 (Abstract)

Palma GA, Clement-Sengewald A, Berg U and Brem G (1992) Role of the embryo number in the development of in vitro produced bovine embryos Theriogenology 37271 (Abstract)

Palma GA, Krefft H, Clement-Sengewald A, Zhu J and Brem G (1993) Results of large in vitro bovine embryo production Proceedings of the 10th Scientific Meeting of European Embryo Transfer Association France 250 (Abstract)

Palma GA, Wolf E and Brem G (1995) Effect of growth factors IGF-I, EGF, TDGF- $\alpha$ and PDGF in a protein-free medium on the development of IVM/IVF bovine embryos. In Reproduction and Animal Breeding Advances and Strategy pp 425-426 Eds G Enne, GF Greppi and A Lauria. Elsevier, Amsterdam

Paria BC and Dey SK (1990) Preimplantation embryo development in vitro: cooperative interactions among embryos and role of growth factors Developmental Biology 87 4756-4760

Persson E, Rodriguez-Martinez H, Dantzer V (1992) Immunocytochemical localization of growth factors during porcine placentation Proceedings of the 12th International Congress on Animal Reproduction (The Hague) 3 1267-1269

Rinderknecht E, Humbel RE (1988) The amino acid sequence of human insulin-like growth factor I and its structural homology with proinsulin Journal of Biological Chemistry $3636233-6239$

Schams D, Graf F, Meyer J, Graule B, Mauthner M and Wollny C (1991) Changes of hormones, metabolites and milk after treatment with sometribove (recombinant methionyl bst) in Deutsches Fleck- and German Black and White cows Journal of Animal Science 69 1583-1592

Schultz GA., Hogan A, Watson A, Smith RM and Heyner S (1992) Insulinlike growth factors and glucose transporters temporal patterns of gene expression in early murine and bovine embryos Reproduction Fertility and Development 4 361-371

Simmen RCM, Ko Y, Simmen FA (1993) Insulin-like growth factors and blastocyst development Theriogenology 39 163-175

Spicer LJ, Alpisar E and Echternkamp SE (1993) Effects of insulin-like growth factor I, and gonadotropins on bovine granulosa cell proliferation, progesterone production, estradiol production and (or) insulin-like growth factor I production in vitro. Journal of Animal Science 71 1232-1241

Thibodeaux JK, Myers MW, Prough SG and White KL (1995) Effect of serum extender containing growth factors on development of IVM and IVF bovine embryos. Theriogenology 44 423-432

Veldhuis JD and Rogers RJ (1987) Mechanisms subserving the steroidogenic synergism between follicle-stimulating hormone and insulin-like growth factor I (somatomedin C) Journal of Biological Chemistry 262 7658-7664

Walker SK, TM Heard and Seamark RF (1992) In vitro culture of sheep embryos without co-culture success and perspectives Theriogenology 37 111-116

Wiley L, Yamami MS and Van Muydon D (1986) Effect of potassium, type of protein supplement and embryo density on mouse preimplantation development in vitro Fertility and Sterility 45 111-119

Willemsen D, Palma GA and Wolf E (1995) Vitrification of in vitro-produced bovine embryos after culture in medium supplemented with insulin-like growth factor-I (IGF-I) Theriogenology 43352 (Abstract) 